DOI: https://doi.org/10.32839/2304-5809/2021-3-91-49

УДК 811.161.1:81-119

Кірілічева В.О.

Інститут мовознавства імені О.О. Потебні

Національної академії наук України

\title{
КОНЦЕПТ «БЕСІДА» («БЕСЕДА») В ЦИФРОВУ ЕПОХУ: ФРЕЙМОВО-ДИСКУРСИВНЕ МОДЕЛЮВАННЯ
}

\begin{abstract}
Анотація. Стаття присвячена дослідженню концепта «беседа» в цифрову епоху із застосуванням фрреймоводискурсивного моделювання. Метою статті є побудувати фреймову модель бесіди цифрової епохи (типової бесіди в соцмережах) шляхом зіставлення їі зі спонтанною бесідою періоду доцифрового спілкування. Дослідження загрунтоване на осмисленні 100 реакцій (50 від російськомовних і 50 від англомовних респондентів) на стимули «бесіда», «соцмережа», «інтернет», отриманих шляхом проведення кількафразного експерименту з асоціативним компонентом (визначення соцмереж, включно з аналоговим та за принципом примітивів). В статті узагальнено відомості про інтернет-спілкування, на відміну від реальної комунікації, та природу соцмереж. Фрейм концепту «бесіда цифрової епохи» схарактеризований за виокремленими іманентно об’єкту дослідження позищіями адресант, адресат, тема, характеристики комунікативного акту, структура повідомлення, час, простір, наслідки виконання/невиконання комунікативного акту.
\end{abstract}

Ключові слова: когнітологія, концепт, фрейм, інтернет-простір, соцмережа, російська лінгвокультура.

Kirilicheva Vladena

O.O. Potebnia Institute of Linguistics of the National Academy of Sciences of Ukraine

\section{FRAME OF THE 'BESEDA' CONCEPT IN THE DIGITAL ERA: FRAME-DISCURVISE MODELING}

Summary. The article is dedicated to the analysis of the "conversation" (беседа) concept in the digital era by the means of frame modeling. The aim of the article is to build a frame model of the digital era social networking-specific conversation by comparing it to the informal (spontaneous) pre-digital era conversation. The data are gained through conducting a three-phase free association experiment (with 50 Russian-speaking and 50 English-speaking respondents), during which such stimuli as "conversation", "social networking" and "internet" were used. Participants' responses are divided into three groups, relating to informative, communicative, and self-expressing functions of social networking accordingly. Because "conversation" (беседа) is an example of an informal communicative act, main features and structural elements of informal communication are established (rapport maintenance as the primary goal, absence of purposeful control in turn-taking and switching between topics). The article also explores the nature of Internet-communication as opposed to face-to-face communication, as well as the nature of social networking (and to a lesser extent, social media). In particular, the primarily communicative (informative-communicative) nature of the Internet environment is emphasized. Besides, special attention is paid to defining internet-communication as a special blend between spoken and written communication within which extralinguistic cues (as secondary to the purely textual part of communication) are artificially created and actively manipulated by the user. The article also briefly discusses differences between the digital and the pre-digital types of communication and provides a tentative explanation for the changes related to the digital type. The results are represented through the frame structure consisting of seven slots: addresser-addressee, topic, characteristics, structure, time, space, and consequences of fulfilling / failing to fulfill the requirements specific to the communicative act under observation. The paper suggests theoretical and practical perspectives and directions for future research.

Keywords: cognitology, concept, frame, Internet environment, social networking, Russian linguoculture.

$\Pi^{2}$ остановка проблеми. Одним 3 найперспективніших напрямків дослідження лінгвістичних явищ $є$ когнітивна лінгвістика - напрямок зі спектру комунікативно-фрункціональної парадигми. Цей напрямок передбачає використання ряду методик, серед яких фрреймове та дискурсивне моделювання. Поєднання цих двох підходів до аналізу мовного матеріалу забезпечуе науковця ефрективним інструментарієм для дослідження концептів комунікативних актів загалом (як бесіда, промова, лекція, подібні), оскільки дозволяє водночас спостерігати їх як культурно- і комунікативно-релевантні явища, і для осмислення способів фоннкціонування цих концептів у різних просторах, зокрема, в інтернет-просторі. Дослідження інтернет-простору дозволяе побачити особливості модифікації концептів i, водночас, специфріку цифрового простору як комунікації нового типу.
Аналіз останніх досліджень і публікацій. Осмислення теорії комунікативного акту та особливостей комунікації в інтернет-просторі загрунтоване на працях S. Eggins (особливості недормальної комунікації у порівнянні з недормальною) [20], Г. Почепцова (співвідношення інформативної і комунікативної складових в інтернет-просторі) [9-13], D. Crystal, O. Горошко (природа інтернет-комунікації) [19; 4], Л. Компанцевої (своєрідні риси інтернет-комунікації в цілому та в окремих сфрерах) [7; 8] та ін.

Виділення невирішених раніше частин загальної проблеми. Існуе значна сукупність праць, присвячених дослідженню національнорелевантних концептів і комунікативних актів різних типів, однак спроби фреймово-дискурсивного моделювання концептів комунікативних актів (особливо у зв'язку 3 вивченням їхнього 
фрункціонування в інтернет-просторі) не отримали системного опису загалом і щодо російській лінгвокультури, зокрема.

Формулювання цілей статті. Мета дослідження - описати конщепт «беседа» в цифрову епоху iз застосуванням фрреймово-дискурсивного моделювання та побудувати відповідну фреймову модель.

Дослідження мовно-ментальних параметрів концепту «бесіда ("беседа") цифрової епохи» загрунтоване на осмисленні 100 реакцій (50 від російськомовних і 50 від англомовних респондентів) на стимули «бесіда", «соцмережа», «інтернет», отриманих шляхом проведення експерименту з асоціативним компонентом наприкінці 2019 - на початку 2020 років.

Виклад основного матеріалу дослідження. Оскільки бесіда належить до неформальних комунікативних актів, необхідно, перш за все, визначити природу згаданого типу комунікативних актів. На відміну від формальної комунікаціі (як диалог, разговор, обсуждение и спор), у основі якої є певне «завдання» (в оригіналі "task-oriented communication", наприклад, отримання індрормації або певного товару / послуги), недрормальна комунікащія грунтуеться на підтриманні рапорту і обміні несуттєвою інформацією [20, с. 16]. Оскільки цей процес є практично нескінченним, недормальна комунікащія, на відміну від формальної, яка закінчуеться 3 виконанням «завдання», триває до того часу, поки учасники комунікації виявляють бажання спілкуватися шляхом збереження стабільності в суміжних парах (в оригіналі "adjacency pair" - мінімальна одиниця комунікативного акту, наприклад, питання-відповідь). Отже, підсумовуючи висновки дослідників [16;20;21], успішність недрормальної комунікащії виявляеться нетрадиційно: сам фракт ії тривалості є показником ії успішності. Також необхідною умовою є підтримання взаємності (reciprocity), яка передбачає відносно рівний розподіл сили / енергії (в оригіналі "power") між учасниками комунікативного акту [20, с. 12]. Отже, в своєму ідеальному варіанті нефрормальна комунікація, на відміну від формальної, вирізняеться відсутністю: а) контролювання тем, б) контролювання черговості висловлювань ("turns"). Cеред найпоширеніших інструментів підтримання рапорту можна назвати «підхід» ("approach"), який $є$ своєрідним універсальним виявленням англійського концепту "small talk", сутність якого полягає в підготовці до введення більш змістовних тем ("centering") [24].

Опис фррейму концепту «беседа» в цифрову епоху потребує дослідження іманентного середовища його функціонування - соцмережі. Хоча інтернет як френомен з'явився ще в 1983 рощі, його використання в традиційному смислі слова стало можливим трохи пізніше - на початку 1990-х років, коли з'явилася так звана «Глобальна павутина» (World Wide Web). Активація комунікативної фрункції була, ймовірно, найголовнішим етапом у розвитку інтернету, який, за визначенням А. Долгіна, перетворився з «супербібліотеки» на «супер-телеграфр» [5]. Отже, тоді як в ранньому форумному спілкуванні (наприклад, Usenet) акцентувалися теми, тобто первинність належала контенту, пізніше почали з'являтися «егоцентричні» платформи, спрямовані на особистість (наприклад, Facebook, Linkedln тощо)
[18, с. 219]. Форумне спілкування є прикладом дискусійного, оскільки воно підпорядковане певній темі та певній меті (найчастіше - знайти відповідь на певне питання). У цьому сенсі форуми можна назвати своєрідною «проміжною ланкою» між індормащійною і комунікативною епохами. Тоді як соцмережі є комунікативно-орієнтованими, соцмедіа, навпроти, $є$ інформаційно-орієнтованими, хоча комунікативний елемент у них також є доволі активним.

Оскільки однією з умов вебу 2.0. було всезагальне створення та поширення контенту, в основі соцмедіа лежить двосторонній принцип викладення контенту в мережу. Контент може бути створений самим користувачем або дуплікований (reblogged / reposted) від іншого користувача та містити реакцію на контент, і саме "реакції являють собою вже згаданий комунікативний елемент, імплікований частиною «соц». Для позначення цього френомену О. Горошко використовуе метафpopy ReadWrite Web, «велетенської шкільної дошки для всіх» (переклад наш), або, іншими словами, простору, в якому можна читати и писати водночас [4, с. 12]. Відгалуження ціеї метафори - «архітектура чорної дошки» (blackboard architecture) являє собою один 3 інструментів досягнення взаєморозуміння між політиками через демонстрацію їхніх думок / трансорормащій цих думок на спільний дощці [16, с. 38]. Г. Почепцов пише про беззаперечне домінування в цифровій copepi комунікативного простору над інформативним або, іншими словами, поглинання першого другим, що є прямим наслідком трансдормаційної сили віртуального простору, здатного підпорядковувати собі певні елементи реальності $[9 ; 10]$. Як зазначає дослідник, інорормація як така вже сприймаеться не як беззаперечна істина, сталий набір фрактів (асертивів), що було характерним для минулих епох, а як щось передане одним співрозмовником іншому, де це «щось» є фрактично «серцевиною» комунікативного акту, "каталізатором» його подовження, і це знову вказуе на домінантну природу комунікативного простору над інформативним [11; 12]. Л. Компанцева також наголошуе на тому, що існуе пряма залежність між індормованістю, розгалуженістю інтернет-простору та динамікою комунікації [8]. Таким чином, інтернет фрактично змінив вектор свого розвитку, перетворившись 3 інформаційної мережі на інформаційно-комунікативну, а згодом, коли головною вимогою для контенту стала його демократичність (тобто доступність для вільного сприйняття та обговорення), і на майже цілковито комунікативну.

Масовий контент доступний великій кількості людей; відповідно, комунікація довкола нього відбувається за принципом «один-до-багатьох» ("broadcasting", на відміну від "narrowcasting", «один-до-одного»), або, за термінологією Г. Почепцова, за принципом "рупора", тобто, по суті, адресата як такого немає, оскільки ця інформація може бути отримана необмеженою кількістю користувачів [13; 17]. Дослідження свідчать, що чим «більш розмитим» $є$ адресат, тим більш егоцентричним $є$ контент, спрямований на цього адресата. Зрештою, можна навіть говорити, що контент набуває риси щоденника, а отже фрункції «автокомунікації», тобто комунікації, за 
якої адресант і адресат повідомлення - одна особа, оскільки повідомлення ніби створено для адресатів (в технічному сенсі), але їхне коло $\epsilon$ невизначеним i, відповідно, не може вплинути на характер повідомлення [6, с. 198]. За таких умов замість позиції адресата утворюеться порожне місце, що цілком нівелюе можливість традиційної комунікації і традиційної структуризації тексту як такого, в якому, на думку О. Воробйової [3], адресованість є однією з найголовніших текстових категорій. Згадаймо, що першою російськомовною версією інтернет-блогів були саме інтернет-щоденники [1]. Функція "Question to Follower" представляе собою інший тип комунікації - «один-до-обмеженої кількості». Іншими засобами обмеження потенційного кола адресатів є фоункція «згадування» (для якої використовується значок “@” [22]). Однак, така обмеженість все одно є умовною: якщо публікація зі «згадуванням» $е$ загальнодоступною, це «згадування» швидше виступає як акцентування, ніж справжня адресація. Імітаціею спілкування «один-на-один», або спілкування 3 обмеженою кількістю людей, $е$ фрункція груп (groups) або приватних повідомлень (комунікація за допомогою пошти детально не розглядається, оскільки вона виходить за межі соцмереж і є окремим френоменом). Оскільки групова комунікація заснована найчастіше на вирішенні якогось завдання, вона $є$ дискусійною за природою, а отже, у відповідності до раніше розглянутої теорії, не може вважатися спонтанною та неформальною.

Велика кількість дослідників наголошують на гібридній природі інтернет-комунікації і визначають їі як усно-письмову, оскільки вона поєднуе характеристики усного та письмового мовлення [4, c. 15]. Так, D. Crystal пропонуе визначати інтернет-комунікацію як: а) спонтанну; б) вільно структуровану; в) прив'язану до часу та простору; г) деконтекстуалізовану [19].

В інтернет-комунікації, яка імітуе усний комунікативний акт, відсутність ситуативних знаків - усталених шаблонів - викликає певні труднощі, які можна усунути шляхом створення унікальних для інтернет-комунікації атрибутів [19]. Серед таких атрибутів можна виділити:

- емотикони (позначення, що передають емоційний стан мовця);

- структури (в тому числі пунктуащійні), які імітують фонетичні особливості повідомлення, засновані, відповідно, на комунікативному намірі мовця (наприклад, курсив або надрядкова зірочка для логічного наголосу на певному слові: капіталізащія для імітації крику або особливого акцентування; пробіл між літерами слова для імітації його повільної «промови», зазвичай для постановки акценту або в іронічних цілях; також нетрадиційне використання пунктуащії - наприклад, використання 3+ окличних / питальних знаків для посилення прагматичної складової повідомлення);

- структури / позначки для фріксації екстралінгвістичних обставин комунікативного акту (наприклад, іноді надрядкові зірочки використовують також для згадування супутніх комунікативному акту дій; крім того, існують спеціальні емотикони типу "чашка чаю» або "квітка», які вводять в інтернет-комунікацію символи реальних об'єктів і наближують інтернет-комунікацію до реальної) [23].
В ході експерименту 3 асоціативним компонентом було опитано 50 російськомовних і 50 англомовних (переважно британських) респондентів. Експеримент було поділено на дві частини: у першій частині респонденти були заохочені висловити свої думки щодо різнищі між поняттями «Інтернет» і «соџмережа», тоді як у другій частині їм було запропоновано: а) визначити поняття «соцмережа»; б) надати список асоціацій до цього поняття; в) уявити ситуацію, в якій їм було б необхідно пояснити значення поняття «соцмережа» людині, достеменно (за віком) не обізнаній 3 цим феноменом (дитині, людині похилого віку тощо).

Більшість російськомовних респондентів дотримуеться думки, що соцмережа - маленька та непревалююча частина Інтернету, існування якої, відповідно, залежить від існування Інтернету. Для пояснення цього зв'язку респондентами були використані наступні гіпо-гіперонімічні аналогії: риба (соцмережа) у воді (Інтернеті), товар (соцмережа) в магазині (інтернеті). На відміну від російськомовних, велика частка англомовних респондентів зауважила, що, хоча теза про соцмережу як частину цілого (інтернету) цілком логічна, соцмережі - домінантна частина інтернету, оскільки вони є найбільш відвідуваними та оскільки переважна частина інформації так чи інакше проходить "обробку» соцмережами (так званий recyclying (reblogging / respoting) інформації, що включає як її копіювання, так і цілковиту переробку).

Щодо визначення «соцмережі», то відповіді російськомовних респондентів можна поділити на три групи: 1) соцмережа як інформаційне сховище (наприклад, глобальный справочник, у тому числі пошук інфрормащії про людей шляхом представлення соцмережі як адресной / контактной книги, картотеки / набора анкет); 2) соцмережа як засіб спілкування (підкреслено можливість єдності на основі спільних інтересів, соцмережу представлено як сообшество / груnпа, кружок по интересал); 3) соцмережа як засіб самовираження (наприклад, дневник). Іноді визначення були представлені у вигляді компонентів ряду 3 гіпо-гіперонімічними відносинами «соцмережа-конкретний сайт / платформа» та «інформація в соцмережі-конкретна форма подачі цієї інформації»: найчастіше згадували Вконтакте, Однаклассники та Facebook (рідше - Twitter, Instagram); в інфрормаційному полі соцмережі найчастіше зустрічаються новини i, відповідно, їх обговорення як прямий наслідок комунікативної природи соцмережі. Суб'єктами поширення інформації / комунікації є гуртки / кола / натовпи людей, штучно «поділені» спільними інтересами. Кожна така особистість є віртуальною особистістю [7], тобто протилежністю реальної особистості, що створюе унікальну ситуацію «двійництва» та гри. Одним із центральних атрибутів інформаційно-комунікативної сфери є лногофункииональность, разом з мгновенностью та доступностью. Відповідно, хронотоп соцмережі як віддзеркалення цих властивостей, характеризується максимальною свободою доступу, яка може бути визначена наступною dpopмулою: «де завгодно та коли завгодно». Серед вербалізащї топосів найбільш частотним є $у д а$ ленность / дистанционность, тобто можливість 
наявності певної дистанції між мовцем1 і мовцем2, яка не перешкоджає комунікації. Особливо чітко своєрідність хронотопу соцмереж виявлено в порівнянні 3 іншими, більш архаїчними каналами комунікації, такими як телефон і традиційне листування. Так, в експлікативній (пояснювальній) частині експерименту переважала думка про те, що соцмережа - «миттево доставлений лист», «велика будівля, яка вміщуе всіх незалежно від їхнього розташування» або «загальнодоступний щоденник, тобто такий, який можуть бачити всі й завжди». Метафора щоденника співвідноситься з уже описаною метадророю «загальнодоступної дошки» і вказуе на стирання меж між адресатом і адресантом, а також відкриту до (часто фррагментарних, «аплікаційних») трансдормацій комунікацію [1, с. 248]. Всі ці визначення вказують на цілковите стирання локусу та частково хроносу як нерелевантних для інтернетівського спілкування в його інформаційно-комунікативному аспекті.

Ще одна велика частка відповідей респондентів - реакції-атрибути з явно вираженим оцінним компонентом, які представляють третю групу відповідей («соцмережа як засіб самовираження»); вони радикально відрізняються від двох попередніх. У відповідях цієї групи домінуе негативна оцінка. Порівняно позитивні характеристики подано лише в експлікативному опитувальнику, але їхній вияв тісно пов'язаний з тими випадками, коли соцмережу визначено через інші, менш сучасні засоби спілкування. Іншими словами, нереалізовані потенщії цих засобів (телефон, листування, «загальний» щоденник) осмислено в більш позитивному руслі, ніж реалізація цих потенцій у соцмережі. Сдине цілком позитивне визначення соцмережі пов'язане 3 ї̈ заощаджувальною фрункцією («не надо тратиться на ларки»). Відповідно, більш позитивна моментальность схарактеризована як спешка / суету, мобильность - як безделье / лень. Типовий суб'єкт комунікацї - «віртуальний двійник» - продукуе ряд негативно забарвлених присудкових атрибутів, серед яких тщеславие / салореклала ("палятник тшеславию»), ложь, поверхностность.

Відповідно, в цьому антропоцентричному вимірі конкретизовано і хронотоп, хоча все одно він залишається носієм семантики нейтралізащії традиційного часу / місця як наслідку надмірного вибору. Ця семантика додатково підсилюється семантикою «дурного простору». Час у соцмережах можна описати як «стійке зараз», яке фрактично нейтралізуе минуле й майбутне, які «принесені в жертву» вже зазначеній миттевості створення / переробки нового контенту. Такий час респонденти визначають як «витрачений» / «убитий», тобто, іншими словами, неживий. У цьому плані утворюеться дещо несподівана опозиція 3 індрормаційно-комунікативним розумінням часу, який, перш за все, постає як всеохоплюючий і мобільний: суб'єктивне опрацювання такої мобільності, очевидно, зазнає невдачі і, відповідно, перетворюе «плюс» на «мінус». У мірологічному сенсі, такий сталий (зафріксований на точці «зараз») «абсолютний» час є ознакою «антисвіту» або хаосу - тобто несприятливого для людини середовища, такого, в якому вона не може нормально існувати $[15$, с. 21]. «Топосні» відпо- віді респондентів підтримують цю тезу: елемент «нерухомості», "відсутності життя» відображено в дурних просторах болото, яла, свалка (але така, з якої можна інколи взяти щось корисне). Перші дві асоціації, будучи традиційними маркерами дурного простору, утворюють сакралізований образ соцмереж, тоді як асоціацію свалка можна трактувати як його профанний аналог. Суперечливою в цьому сенсі асоціацією є круг (nо интересал), який, на відміну від загального осмислення хронотопа соцмережі як «безмежного», являє собою чітку локалізацію виртуальной личности шляхом її обмеження сакральним символом кола. У міфрологічному аспекті таке коло може трактуватися як: а) відгалуження міфрологічного «золотого кола» - символу раю; б) «отвір» у потойбіччя як неприродне для людини середовище [15, с. 22-23].

Самі інтернет-користувачі, однак, такі кола за інтересами трактують як сприятливий, навіть ідеалізований простір, в якому починається гра віртуальної особистості з інформацією (за визначенням одного з респондентів, ивыставление себя в свете постановочных собылтий»). Така гра, однак, також є символом необмеженості, безкінечності, оскільки: а) інформація, 3 якою людина "грає», є необмеженою; б) існуе безліч варіантів / комбінацій такої ігри; в) існуе безліч ігор. Така безмежність вибору вказує на ентропію, а отже, існування в ненатуральному часопростоpi - «антисвіті» [15, с. 21]. Таким чином, хронотоп соціальних мереж у суб'єктивному осмисленні постає як: 1) ненатуральний для людини, її звичайного відчуття часу / місця i, відповідно, такий, що змушуе їі шукати «захисту» через курсування між сакралізацією та профранізацією з метою приниження / виявлення залежності від соціальних мереж; 2) як такий, який активує бажання людини «грати» i, навпаки, посилює їі залежність від гри.

Англомовні респонденти, на відміну від російськомовних, частіше вдавалися до об'єктиващії гіпо-гіперономічні відносин ряду позначень «соцмережі», а саме - назв сайтів / платформ (Facebook, Twitter, Instagram, рідше Reddit) і типів / форм інформації, представлених у цих соцмережах (новини, мистецтво, музика; картинки, меми і т.п.). В аспекті функцій інтернет-комунікації, подібно до російськомовних респондентів, англомовні респонденти визначали соцмережі як об'єднання людей за спільними інтересами / поділеними думками (shared interests / opinions), які збирають людей разом, створюють передумови для їхньої соціальної активності (social engagement), яка потребуе постійного підтримання зв'язку (connecting / reconnecting). Більше того, відповіді англомовних респондентів містять додатковий акцент на варіативності такої активності ("congregation of large numbers"), поясненій як потенщійна можливість зустрітися 3 великою кількістю людей, що водночас підвищуе можливість зустріти людей зі спільними інтересами ("one almost always ends up interacting largely with people who think similarly about the world"). Таким чином, крім звичайної локалізації за групами, відбувається локалізація за суб'єктами, мета яких - знаходження спільних інтересів. Так, серед згаданих локацій можна назвати: room with tables (кімната зі столами), beehive 
(вулик). Кімнату співвіднесено з російським еквівалентом "великого будинку», тоді як аналога вулика немає - все локації російськомовних респондентів (за винятком круга) є негативно забарвленими, тоді як вулик - символ не лише активності (social engagement), а й спільної плідної праці (sharing of interests / opinions).

Стала, навіть стагнащійна сутність хронотопу соцмережі в осмисленні російськомовними респондентами у відповідях англомовних респондентів також набула інших своєрідних характеристик: англомовні респонденти пропонують більш різноманітні форми переосмислення соцмережі, визначаючи ї̈ як потік (flow) та фрільм (movie), тобто швидкорухому сутність, яка дає миттевий доступ до інформації. Проте ці визначення не $є$ однозначно позитивними. Так, flow-потік, який «розносить психологічні риси», тобто, іншими словами впливає на тих, кого він торкається. Звідси походить поділ суб'єктів комунікації на тих, хто впливає (influencers) і тих, хто підкоряеться впливу. Це й було виражено також в описах і російськомовних респондентів, але імпліцитно.

Що стосується наслідків активного користування соцмережею, відповіді англомовних респондентів здебільшого дублюють відповіді російськомовних. Одним помітним відхиленням є додатковий акцент на порушенні приватності (anti-privacy) як дистопічній рисі суспільства. Англомовні респонденти також більш прямолінійні у визнанні залежності від соцмережі (addictive, unhealthy, depressing, stressful) та більш об'єктивні в плані постулювання позитивних наслідків користування соцмережею, серед яких: прозорість / відкритість інформації (transparency, out in the open) за рахунок ії великої кількості та розширення кругозору (expanding awareness) користувача. Таким чином, відповіді англомовних респондентів, на відміну від російськомовних, є більш гармонічними в плані визнання за соцмережею властивості поєднувати об'єктивну інформацію зі своєрідними формами самовираження суб'єктів і водночас служити своєрідною формою комунікації. Це може бути пояснено тим, що домінантне в інтернет-просторі поняття «чат» (chat) як набір певних характеристик комунікації є добре знайомим для англомовних респондентів ще 3 доцифрової комунікативної епохи, тоді як для російськомовних респондентів це поняття, зокрема через його віддаленість від поняття «беседа», є принщипово новим, і тому вони ще не сприймають його як звичну форому комунікації.

Таким чином, побудуємо фррейм концепту «бесіда ("беседа") цифрової епохи», зважаючи на особливості більш традиційної (доцифрової) версії цього комунікативного акту, властивості яูкого докладно подано в працях Ю. Прохорова, Й. Стерніна [14] та I. Борисової [2] і досліджено нами:

1. АДРЕСАТ-АДРЕСАНТ: На відміну від бесіди доцифрової епохи, неможливе спонтанне підключення до комунікативного акту третьої особи (потенційного адресата чи адресанта).

2. TEMA: чітко визначеної теми не існує, існує лише потенційна сукупність тем (як і у випадку з бесідою доцифррової епохи).

3. ХАРАКТЕРИСТИКИ: На відміну від бесіди доцифрової епохи, умови відкритості / від- вертості та задушевності (сакральності) не $\epsilon$ обов'язковими, але ранг обов'язкових набувають умови легкості, дружнього ставлення та позитиву. Крім того, комунікативний акт «бесіда цифрової епохи» $є$ текстоцентричним за природою, а екстралінгвістична складова цього акту може більш жорстко контролюватися його учасниками (користувачами інтернету).

4. СТРУКТУРА: На відміну від бесіди доцифрової, бесіда цифрової епохи є мобільною (швидка зміна реплік) та лінійною, тобто такою, яка відповідає схемі "привітання - обмін "підходами" в формі «питання-відповіды», часто з «віддзеркаленими» питаннями й без надмірної кількості наративів (у бесідах доцифрової епохи існуе тенденція подовжувати репліки суміжних пар шляхом заміни швидких відповідей наративними конструкціями [2]).

5. ЧАС: За рахунок більш швидкої зміни реплік та меншої кількості пауз бесіда цифрової епохи у середньому потребує меншого проміжку часу, ніж бесіда доцифрової епохи.

6. ПРОСТІР. У широкому (прямому) сенсі. На відміну від бесіди доцифрової епохи, фрізичний простір бесіди циорової епохи знівельовано внаслідок ототожнення безкінечного географрічного простору та ілюзорно малого (легко досяжного) інтернет-простору. Варто зазначити й те, що цей простір іноді сприймається не в нейтральному / позитивному, а й у негативному сенсі.

У вузькому сенсі («наповнення»). На відміну від бесіди доцифрової епохи, є обмеженим, цілком підпорядкованим творцю комунікативного акту, який повністю контролюе його, та використовуеться для акцентування тексту як основного елементу. ПРОСТІР у вузькому сенсі можна поділити на субслоти. Це ЗАСОБИ ВИРАЖЕННЯ ЕМОЦІЙНОГО СТАНУ: а) емотикони-смайли; б) емотикони-жести; в) графрічні засоби фонетичних особливостей мовлення. ЗАСОБИ ПЕРЕДАЧ СУПУТНІХ КОМУНІКАТИВНОМУ АКТУ ДІЙ: а) емотикони-об'єкти; б) інші графрічні засоби.

7. НАСЛІДКИ ВИКОНАННЯ / НЕВИКОНАННЯ ПРАВИЛ КОМУНІКАТИВНОГО АКТУ (КА). КА є успішним, якщо той, хто хоче висловитися, вміє регулювати комунікативний простір шляхом створення / усунення об'єктів, підпорядковуючи цю регуляцію своїй комунікативній інтенції.

\section{Висновки і пропозиції.}

1. Основною особливістю бесіди як недрормального комунікативного акту є встановлення та підтримання рапорту, а їі основними характеристиками є відсутність контролювання порядку висловлювань учасників комунікативного акту та відсутність контролювання топіків.

2. Інтернет-простір як основна середа існування концепту «бесіда "беседа" цифрової епохи» $є$ більшою мірою комунікативним, ніж інформативним явищем. Соцмережа та соцмедіа, основні відгалуження даного простору, $є$ відображенням його інформативно-комунікативного балансу, який передбачає підпорядкування інфрормації комунікативним вимогам, а отже, створення нового типу інформації 3 фрактично нейтралізованими ролями творця та споживача. Переважна частка інтернет-комунікації $е$ комунікацією «один-до-всіх», тоді як комунікація «один-до-обмеженої кількості» можлива лише 
в приватних повідомленнях, що являють собою аналог недормальної бесіди.

3. Побудована фреймова модель містить наступні слоти: адресат-адресант, тема, характеристики, структура, час, простір (у широкому та вузькому сенсі), наслідки виконання / невиконання правил комунікативного акту.

4. Схематично окреслені відмінності традиційної (доцифрової) комунікації від сучасної (цифрової) можуть бути частково пояснені трансформаціею російськомовної бесіди інтернет-простору в її англомовний умовний аналог "chat", що могло бути зумовлено зміною фрізичного простору комунікативного акту на соціокультурно обумовлений технічний простір.

Таким чином, концепт «бесіда "беседа" цифррової епохи» зазнає наступних змін: а) «полегшення» характеру бесіди в плані набуття можливості обговорювати більш поверхневі, менш серйозні фpiлософрські теми; б) деяке «послаблення» умов відкритості / відвертості та задушевності, виконання / невиконання яких залишено на розсуд учасників комунікативного акту; в) зниження демократичності комунікації за рахунок надання користувачам можливості змінювати комунікативний інтернет-простір «відповідно до своїх потреб»; г) зміна структури бесіди через пришвидшення зміни суміжних пар, вирівнювання структури комунікативного акту та зменшення кількості наративів.

Перспективами подальшого дослідження концепту «бесіда» ("беседа") є посилення компаративного аспекту (шляхом залучення даних інших мов) та увиразнення - 3 плином часу - діахронічного аспекту дослідження бесіди цифрової епохи.

\section{Список літератури:}

1. Белова Ю.С. Інтернет-щоденник як засіб інтерпретації образу автора (на матеріалі книги Є. Гришковця «Рік життя». Наукові записки ТНПУ. Серія : Літературознавство. 2016. № 44. С. $247-249$. URL: http://dspace.tnpu.edu.ua/bitstream/123456789/6842/1/Belova.pdf (дата звернення: 10.11.2020).

2. Борисова И.Н. Русское повседневное общение: прагматика, культурология : монография / под. ред. профр. И.Н. Борисовой. Екатеринбург, 2018. 442 с.

3. Воробьева О.П. Текстовые категории и фактор адресата. Київ, 1993. 200 с.

4. Горошко Е.И. Гипертекст 3.0: лингвистический анализ. Гипертекст как объект лингвистического исследования : материаль Всероссийской научно-практической конферениии с международныл участиел, 15 марта 2010. Самара, 2010. 172 с.

5. Долгин А.Б. Рунет: игра на опережение. Что такое web 3.0? Полит.Py. 2008. URL: https://polit.ru/ article/2008/04/02/web3/ (дата звернення: 10.11.2020).

6. Ігнатьева С.Є. Функціонально-комунікативний простір в українському щоденниковому дискурсі. Філологічні студї. Науковий вісник Криворізького державного педагогічного університету. 2012. Випуск 7. C. 194-204. URL: http://nbuv.gov.ua/UJRN/PhSt_2012_7_22 (дата звернення: 10.11.2020).

7. Компанцева Л.Ф. Інтернет-лінгвістика : підручник. Луганськ, 2012. 300 с.

8. Компанцева Л.Ф. Лінгвістична експертиза соціальних мереж : підручник. Київ, 2018. 318 с.

9. Почепцов Г. В телесериалах, как и в соцмедиа, каждый может найти если не счастье, то комфорт. Детекmop Media. 2019. URL: https://ms.detector.media/mediaanalitika/post/23011/2019-06-09-v-teleserialakh-kak-i-vsotsmedia-kazhdyi-mozhet-naiti-esli-ne-schaste-to-komfort/ (дата звернення: 10.11.2020).

10. Почепцов Г. Когнитивное пространство населения форматируют режиссеры и сценаристы... И только потом журналисты. Детектор медіа. 2019. URL: https://ms.detector.media/mediaanalitika/post/23942/2019-12-15kognytyvnoe-prostranstvo-naselenyya-formatyruyut-rezhyssery-y-stsenarysty-y-tolko-potom-zhurnalysty/ (дата звернення: 10.11.2020).

11. Почепцов Г. Коммуникации переводят человечество на новый уровень развития. Детектор ледіа. 2019. URL: https://ms.detector.media/mediaanalitika/post/23839/2019-11-24-kommunikatsii-perevodyat-chelovechestvona-novyi-uroven-razvitiya/ (дата звернення: 10.11.2020).

12. Почепцов Г. Поп-информация, пришедшая на смену традиционной. Детектор медіa. 2019. URL: https://ms.detector.media/mediaanalitika/post/22711/2019-04-07-pop-informatsiya-prishedshaya-na-smenutraditsionnoi/ (дата звернення: 10.11.2020).

13. Почепцов Г. Соцмедиа и дезинформация: как это все работает. Детектор медіa. 2018. URL:https://ms.detector.media/mediaanalitika/post/22116/2018-11-25-sotsmedia-i-dezinformatsiya-kak-jeto-vserabotaet/ (дата звернення: 10.11.2020).

14. Прохоров Ю.Е., Стернин И.А. Русские: коммуникативное поведение. Москва, 2006. 326 с.

15. Слухай Н.В. Етноконцепти та міфологія східних слов'ян в аспекті лінгвокультурології. Київ, 2005.167 с.

16. Штерн І.Б. Вибрані топіки та лексикон сучасної лінгвістики: Енциклопедичний словник. Київ, 1998. 336 с.

17. Barasch A., Berger J. Broadcasting and narrowcasting: How audience size affects what people share. Journal of Marketing Research. 2014. Vol. 51. P. 286-299. DOI: 10.1509/jmr.13.0238

18. Boyd D., Ellison N.B. Social Network Sites: Definition, History, and Scholarship. Journal of Computer-Mediated Communication. 2008. Vol. 13. Iss. 1. P. 210-230. URL: https://onlinelibrary.wiley.com/doi/epdf/10.1111/j.10836101.2007.00393.x (дата звернення: 10.11.2020).

19. Crystal D. Language and the Internet. UK: Cambridge University Press. 2001. 272 p. DOI: 10.1017/CBO9781139164771

20. Eggins S.E. Keeping the conversation going: A systemic-functional analysis of conversational structure in casual sustained talk. Volume 1. University of Sidney. 1990. 312 p. URL: https://ses.library.usyd.edu.au/handle/ 2123/1003 (дата звернення: 10.11.2020).

21. Gilmartin E., Saam C., Vogel C., Campbell N., Wade V. Just Talking - Modelling Casual Conversation. Proceedings of the SIGDIAL 2018 Conference (Australia, Melbourne, 12-14 July 2018). Melbourne, 2018. P. 51-59. URL: https://www.aclweb.org/anthology/W18-5006.pdf (дата звернення: 10.11.2020).

22. Horton W.S. Theories and Approaches to the Study of Conversation and Interactive Discourse. Handbook of Discourse Processes, 2nd Edition. New York: Routledge, 2018. P. 22-68.

23. Kačmárová A. Internet Chatting Inside Out. SKASE Journal Of Theoretical Linguistics. 2005. Vol. 2. № 1. P. $55-83$. URL: http://www.skase.sk/Volumes/JTL02/05.pdf (дата звернення: 10.11.2020).

24. Ventola E. The structure of casual conversation in English. Journal of Pragmatics. 1979. Vol. 3. Iss. 3. P. $267-298$. DOI: 10.1016/0378-2166(79)90034-1 


\section{References:}

1. Belova Ju. S. (2016) Internet-shhodennyk jak zasib interpretaciji obrazu avtora (na materiali knyghy Je. Ghryshkovcja "Rik zhyttja» [Internet-diary as the means of interpretation of the author's image (based on Grishkovetz's "A Year in Life")]. Naukovi zapysky TNPU. Serija: Literaturoznavstvo [Scientific Proceedings of TNPU. Series: Literary Criticism], no. 44, pp. 247-249. Available at: http://dspace.tnpu.edu.ua/ bitstream/123456789/6842/1/Belova.pdf (accessed 10 November 2020).

2. Borisova I. N. (ed.) (2018) Russkoe povsednevnoe obshhenie: pragmatika, kul'turologija: monografija [Russian everyday communication: pragmatics, culturology: monograph]. Ekaterinburg: Gumanitarnyj universitet (Ekaterinburg). (in Russian)

3. Vorob'eva O. P. (1993) Tekstovye kategorii i faktor adresata: monografiya [Text categories and addressee factor: monograph]. Kyiv: Vyshha shkola. (in Russian)

4. Goroshko E. I. (2010) Gipertekst 3.0: lingvisticheskiy analiz [Hypertext 3.0: linguistic analysis]. Materialy Vserossijskoj nauchno-prakticheskoj konferencii "Gipertekst kak ob'ekt lingvisticheskogo issledovanija [Materials of the all-Russian scientific-practical conference «Hypertext as an object of linguistic research»]. Samara: PGSGA. (in Russian)

5. Dolgin A. B. (2008) Runet: igra na operezhenie. Chto takoe web 3.0 [Runet: taking the lead. What is Web 3.0]? Polit.Ru. Available at: https://polit.ru/article/2008/04/02/web3/ (accessed 10 November 2020).

6. Ighnatjjeva S. Je. (2012) Funkcionaljno-komunikatyvnyj prostir v ukrajinsjkomu shhodennykovomu dyskursi [Functional-communicative space in Ukrainian diary discourse]. Filologhichni studiji. Naukovyj visnyk Kryvorizjkogho derzhavnogho pedaghoghichnogho universytetu [Philological Studies: Scientific Bulletin of Kryvyi Rih State Pedagogical University], vol. 7, pp. 194-204. Available at: http://nbuv.gov.ua/UJRN/PhSt_ 2012_7_22 (accessed 10 November 2020).

7. Kompanceva L. F. (2012) Internet-linghvistyka: pidruchnyk [Internet linguistics: textbook]. Lugansk: Jantar. (in Ukrainian)

8. Kompanceva L. F. (2018) Linghvistychna ekspertyza socialjnykh merezh: pidruchnyk [Linguistic examination of social networks: textbook]. Kyiv: Aghrar Media Ghrup. (in Ukrainian)

9. Pocheptsov G. (2019) V teleserialakh, kak i v sotsmedia, kazhdyy mozhet nayti esli ne schast'e, to komfort [In TV series, like in social media, everyone can find at least comfort if not happiness]. Detektor Media [Detector Media]. Available at: https://ms.detector.media/mediaanalitika/post/23011/2019-06-09-v-teleserialakh-kak-i-vsotsmedia-kazhdyi-mozhet-naiti-esli-ne-schaste-to-komfort/ (accessed 10 November 2020).

10. Pocheptsov G. (2019) Kognitivnoe prostranstvo naseleniya formatiruyut rezhissery i stsenaristy... I tol'ko potom zhurnalisty [Cognitive environment of the population is formed by directors and screenwriters... and only after that by journalists]. Detektor media [Detector Media]. Available at: https://ms.detector.media/mediaanalitika/ post/23942/2019-12-15-kognytyvnoe-prostranstvo-naselenyya-formatyruyut-rezhyssery-y-stsenarysty-y-tolkopotom-zhurnalysty/ (accessed 10 November 2020).

11. Pocheptsov G. (2019) Kommunikatsii perevodyat chelovechestvo na novyy uroven' razvitiya [Communications take humanity to a new level of development]. Detektor media [Detector Media]. Available at: https://ms.detector.media/ mediaanalitika/post/23839/2019-11-24-kommunikatsii-perevodyat-chelovechestvo-na-novyi-uroven-razvitiya/ (accessed 10 November 2020).

12. Pocheptsov G. (2019) Pop-informatsiya, prishedshaya na smenu traditsionnoy []. Detektor media [Detector Media]. Available at: https://ms.detector.media/mediaanalitika/post/22711/2019-04-07-pop-informatsiya-prishedshayana-smenu-traditsionnoi/ (accessed 10 November 2020).

13. Pocheptsov G. (2018) Sotsmedia i dezinformatsiya: kak eto vse rabotaet [Social media and disinformation: how does it work]. Detektor media [Detector Media]. Available at: https://ms.detector.media/mediaanalitika/ post/22116/2018-11-25-sotsmedia-i-dezinformatsiya-kak-jeto-vse-rabotaet/ (accessed 10 November 2020).

14. Prohorov Ju. E., Sternin I. A. (2006) Russkie: kommunikativnoe povedenie [Russians: communicative behavior]. Moscow: Flinta: Nauka. (in Russian)

15. Slukhaj N. V. (2005) Etnokoncepty ta mifologhija skhidnykh slov'jan v aspekti linghvokuljturologhiji [Ethnoconepts and mythology of the Eastern Slavs in the linguocultural aspect]. Kyiv: Vydavnycho-polighrafichnyj centr "Kyjivsjkyj universytet". (in Ukrainian)

16. Shtern I. B. (1998) Vybrani topiky ta leksykon suchasnoji linghvistyky: Encyklopedychnyj slovnyk [Selected topics and lexicon of modern linguistics. Encyclopedic dictionary]. Kyiv: ArtEk. (in Ukrainian)

17. Barasch A., Berger J. (2014) Broadcasting and narrowcasting: How audience size affects what people share. Journal of Marketing Research, vol. 51, pp. 286-299.

18. Boyd D., Ellison N. B. (2008) Social Network Sites: Definition, History, and Scholarship. Journal of ComputerMediated Communication, vol. 13, iss. 1, pp. 210-230. Available at: https://onlinelibrary.wiley.com/doi/epdf/10.1111/ j.1083-6101.2007.00393.x (accessed 10 November 2020).

19. Crystal D. (2001) Language and the Internet. UK: Cambridge University Press.

20. Eggins S. E. (1990) Keeping the conversation going: A systemic-functional analysis of conversational structure in casual sustained talk, vol. 1. Sidney: University of Sidney. Available at: https://ses.library.usyd.edu.au/ handle/2123/1003 (accessed 10 November 2020).

21. Gilmartin E., Saam C., Vogel C., Campbell N., Wade V. (2018) Just Talking - Modelling Casual Conversation. Proceedings of the SIGDIAL 2018 Conference (Australia, Melbourne, July 12-14, 2018). Melbourne: Association for Computational Linguistics, pp. 51-59. Available at: https://www.aclweb.org/anthology/W18-5006.pdf (accessed 10 November 2020).

22. Horton W. S. (2018) Theories and Approaches to the Study of Conversation and Interactive Discourse. Handbook of Discourse Processes, 2nd Edition. New York: Routledge, pp. 22-68.

23. Kachmarova A. (2005) Internet Chatting Inside Out. SKASE Journal Of Theoretical Linguistics, vol. 2, no. 1, pp. 55-83. Available at: www.skase.sk/Volumes/JTL02/05.pdf (accessed 10 November 2020).

24. Ventola E. (1979) The structure of casual conversation in English. Journal of Pragmatics, vol. 3, iss. 3, pp. $267-298$. 